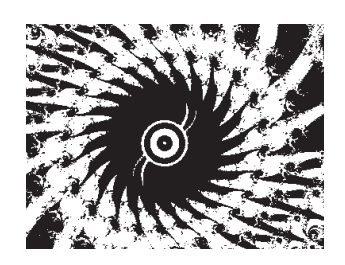

\title{
NOVE SPOZNAJE U ISTRAŽIVANJIMA SAMOPOŚTOVANJA: KONSTRUKT SIGURNOSTI SAMOPOŠTOVANJA
}

Margareta JELIĆ

Filozofski fakultet, Zagreb

UDK: 159.913

Pregledni rad

Primljeno: 27. 1. 2011

Samopoštovanje se vrlo često spominje i u znanstvenoj i u popularnoj literaturi s područja psihologije kao pokazatelj mentalnoga zdravlja, zrele ličnosti i prilagodbe pojedinca. Međutim, u novije vrijeme sve je više kontradiktornih nalaza s područja samopoštovanja, čemu uzrok možemo tražiti u ponešto zastarjelom pristupu istraživanju samopoštovanja, odnosno ignoriranju raznih aspekata samopoštovanja, kao i raznih načina mjerenja samopoštovanja. Cilj ovog rada jest upoznati istraživače s novijim spoznajama u istraživanjima samopoštovanja, upozoriti na kompleksnost ove varijable te dati smiernice za buduća istraživanja. U radu upozoravamo na različite i često kontradiktorne nalaze s obzirom na iskorištene mjere samopoštovanja, posebno vezano uz razinu samopoštovanja. Objašnjavamo i konstrukt sigurnosti samopoštovanja koji može objasniti navedene kontradiktorne nalaze s obzirom na razinu samopoštovanja. Osim definiranja poima sigurnosti samopoštovanja, $u$ radu navodimo moguće operacionalizacije toga konstrukła te razjašnjavamo sličnosti i razlike sa srodnim konstruktima. Konačno, u radu su prikazani rezultati novijih istraživanja samopoštovanja i nove spoznaje s ovoga područja.

Ključne riječi: razina samopoštovanja, sigurnost samopoštovanja, implicitno samopoštovanje, paradoksalno samopoštovanje, obrambeno samopoštovanje

Margareta Jelić, Odsjek za psihologiju, Filozofski fakultet, I. Lučića 3, 10000 Zagreb, Hrvatska.

E-mail: mjelic@ffzg.hr 
Većina ljudi samopoštovanje smatra važnim (Baumeister i sur., 2003.), pa ne začuđuje što se radi o jednoj od najčešće istraživanih varijabli u psihologijskim istraživanjima. Međutim, većina domaćih istraživača promatra samopoštovanje isključivo kao indikator adaptacije. To samo po sebi nije pogrešno, jer samopoštovanje i jest dobar pokazatelj mentalnoga zdravlja ili prilagodbe pojedinca, no smatramo zabrinjavajućim što se $\mathrm{u}$ velikom broju istraživanja, posebno kod nas, rabe neadekvatne mjere samopoštovanja. Tako se npr. često rabi mjera osobnoga samopoštovanja, iako se istražuju međugrupni odnosi, pa bi bilo prikladnije upotrijebiti mjeru kolektivnoga samopoštovanja. Nadalje, $\mathrm{u}$ istraživanjima koja se provode kod nas pretežno se rabi samo mjera općega eksplicitnog samopoštovanja, a ignoriraju se razni aspekti samopoštovanja, kao i implicitne mjere samopoštovanja. Konačno, problematičnim smatramo i upotrebu uglavnom samo razine samopoštovanja u istraživanjima, jer su mnoga istraživanja već potvrdila važnost ispitivanja sigurnosti samopoštovanja. Takav tretman samopoštovanja uzrok je i brojnim kontradiktornim nalazima $u$ literaturi.

Cilj je ovog rada upoznati istraživače s novijim spoznajama o samopoštovanju, upozoriti na kompleksnost ove varijable te dati smjernice za buduća istraživanja. Upozorit ćemo na nalaze s obzirom na primijenjene mjere samopoštovanja te objasniti konstrukt sigurnosti samopoštovanja koji može objasniti kontradiktorne nalaze s obzirom na razinu samopoštovanja. Konačno, navest ćemo moguće operacionalizacije toga konstrukta i upozoriti na sličnosti i razlike s nekim srodnim konstruktima.

\section{STRUKTURA I MJERENJE SAMOPOŠTOVANJA}

Samopoštovanje definiramo kao rezultat formiranoga pojma o sebi, odnosno kao vrednovanje ili evaluaciju sebe. Coopersmith (1967.) pod pojmom samopoštovanje razumijeva evaluaciju koju pojedinac stvara ili održava o sebi, a koja odražava stav prihvaćanja ili odbijanja i upućuje na razinu na kojoj pojedinac sebe doživljava sposobnim, uspješnim, značajnim i vrijednim. Dakle, pojedinci s visokim samopoštovanjem poštuju sebe i smatraju se vrijednima, dok su pojedinci niskoga samopoštovanja skloni odbacivanju sebe, nezadovoljstvu sobom i prijeziru prema sebi (Rosenberg, 1965.). Upravo te spoznaje o važnosti samopoštovanja za svakodnevno funkcioniranje ljudi navele su istraživače na to da sve češće ispituju samopoštovanje kao pokazatelj adaptacije ili dobrobiti pojedinca.

Rana istraživanja samopoštovanja koristila su se isključivo jednodimenzionalnim mjerama samopoštovanja. Kako se 
DRUŠ. ISTRAŽ. ZAGREB GOD. 21 (2012), BR. 2 (116)

STR. $443-463$

JELIĆ, M.:

NOVE SPOZNAJE.. samopoštovanje definira kao evaluacija vlastite slike o sebi, odnosno opći pozitivni ili negativni stav koji pojedinac ima o sebi, mjere samopoštovanja nastojale su zahvatiti upravo taj opći stav pojedinca. Tako se većina skala osobnoga samopoštovanja koje se navode u literaturi temelji na procjeni globalnoga samopoštovanja, odnosno općega zadovoljstva sobom: Kuhn i McPartland TST skala, 1954.; Sherwoodova Self-Concept Inventory skala, 1962.; Rosenbergova RSES, 1965.; Julian, Bishop i Fiedler-ova JBF skala, 1966. (prema Rubin i Hewstone, 1998.). Iako se neki mjerni instrumenti kojima se mjeri samopoštovanje sastoje od specifičnih samoprocjena, smatralo se da je samopoštovanje nedjeljiv konstrukt (Marsh, 1986., prema Tafarodi i Swann, 1995.). Potvrdu takvu pristupu dale su i strukturalne analize mjernih instrumenata samopoštovanja, koje su konzistentno pokazivale nadređeni faktor općega samopoštovanja i niz faktora nižeg reda koji se odnose na specifične facete samoevaluacije (Van Tuinen i Ramanaiah, 1979.; Fleming i Watts, 1980.; Shavelson i Bolus, 1982; Fleming i Courtney, 1984; sve prema Tafarodi i Swann, 1995.).

Međutim, neki autori ovakvu konceptualizaciju samopoštovanja smatraju problematičnom, jer čak i najpoznatiji instrument za mjerenje samopoštovanja - Rosenbergova skala osobnoga samopoštovanja - faktorskom analizom najčešće izlučuje dva faktora. Iako faktori zapravo samo razlikuju pozitivno i negativno formulirane čestice skale, ta je činjenica bila povod detaljnijem promišljanju strukture samopoštovanja. Tako su se istraživači vratili polazištu da samopoštovanje ima niz specifičnih aspekata, odnosno domena na koje se odnosi. Najčešće je $u$ istraživanjima ispitivana akademska ili školska kompetentnost, atletska kompetentnost kada su uzorak činili sportaši, socijalno prihvaćanje, samopoštovanje vezano uz fizički izgled i regulacija ponašanja (Janis i Field, 1959. - Feelings of Inadequacy Scale; Fitts, 1964. - Tennessee Self-Concept Scale; Coopersmith, 1967. - Self-Esteem Inventory; Harter, 1985. - Self-Perception Scale).

No takav pristup raščlanjuje samopoštovanje na niz vrlo specifičnih domena i udaljuje se od njegove izvorne definicije da se radi o općoj evaluaciji sebe. Stoga istraživači razlikuju pojedine domene samopoštovanja, ali prihvaćaju i koncept općega samopoštovanja kao općeg osjećaja vlastite vrijednosti (Coopersmith, 1967.; Harter, 1999.). Takav pristup čini nam se prihvatljivim i logičnim, jer svaki pojedinac može imati različitu procjenu vlastite kompetentnosti na različitim područjima, ali svejedno i opću evaluaciju sebe kao više ili manje vrijedne osobe. K tome, neki modeli samopoimanja, i s njim usko povezanoga samopoštovanja, hijerarhijski su organizirani. Mnoge empirijske potvrde dobio je multidimenzionalni model Shavelsona, Hubnera i Statona (1976.), koji pretpo- 
DRUŠ. ISTRAŽ. ZAGREB GOD. 21 (2012)

BR. 2 (116)

STR. $443-463$

JELIĆ, $M$.

NOVE SPOZNAJE... stavlja hijerarhijsku strukturu samopoštovanja, pri čemu su općenitiji aspekti nadređeni specifičnijima, pa je tako opće samopoštovanje na samom vrhu hijerarhijske strukture. Model također pretpostavlja da su općenitiji aspekti, koji su hijerarhijski viši, ujedno i stabilniji. Međutim, ostaje nerazjašnjeno metodološko pitanje mjerenja samopoštovanja, jer nas i ovaj model vraća na početno pitanje - želimo li mjeriti samopoštovanje kao općenitu evaluaciju sebe i jedinstven konstrukt ili pak želimo zahvatiti mnoštvo specifičnih domena samopoštovanja.

Logično je pretpostaviti da sve domene ipak nisu jednako važne ili presudne za razinu općega samopoštovanja. Stoga su neka novija istraživanja samopoštovanja krenula $u$ smjeru određenja nekoliko "osi" samopoštovanja, tj. domena koje zapravo određuju opće vrednovanje sebe. Vjerojatno najprihvaćenije osi samopoštovanja jesu socijalna vrijednost $\mathrm{i}$ kompetentnost, koje prepoznaju brojni teoretičari (Diggory, 1966.; Brisset, 1972.; Franks i Marolla, 1976.; Gecas i Schwalbe, 1986.; Bandura, 1992.; Harter, 1999.; Brown, 1998.; prema Tafarodi i sur., 2003.). To je u skladu i s Maslowljevom hijerarhijom potreba, u kojoj je samopoštovanje definirano dvjema komponentama: kompetentnošću i poštovanjem iskazanim od drugih. U skladu je i s Harterovom, koja navodi slična dva faktora u podlozi općega samopoštovanja. Izbor te dvije domene nije slučajan, jer odražava dva kriterija kojima se vodimo u samoprocjeni - objektivnoj evaluaciji vlastitih sposobnosti i vještina te evaluaciji utemeljenoj na socijalnoj prihvaćenosti. S takvom se konceptualizacijom slažu i Tafarodi i Swann (1995.), koji domenu prihvaćenosti/neprihvaćenosti nazivaju samosviđanjem (engl. self-liking), a domenu opće vlastite snage ili slabosti zovu samokompetentnost (engl. self-competence). Mnoga istraživanja, prije svega eksploratorne i konfirmatorne faktorske analize te istraživanja diskriminativne valjanosti, potvrdila su ove dvije dimenzije samopoštovanja (Franks i Marolla, 1976.; Openshaw i sur., 1981.; Barber i Thomas, 1986.; Gecas i Schwalbe, 1986.). Tafarodi smatra kako upravo te dvije domene odgovaraju često dobivanoj dvofaktorskoj strukturi Rosenbergove skale samopoštovanja (Ang i sur., 2006.) te potvrđuju dvodimenzionalnost konstrukta samopoštovanja, jer dvije dimenzije različito koreliraju s brojnim relevantnim varijablama poput negativnih životnih događaja ili ponašanjima poput pamćenja i prepoznavanja riječi koje se odnose na socijalnu vrijednost (Tafarodi i Milne, 2002.), ili pak ustrajnosti u rješavanju zadataka nakon pozitivne ili negativne povratne informacije o vlastitoj uspješnosti (Tafarodi i $\mathrm{Vu}, 1997$.). Istraživačima je najzanimljiviji odnos dviju dimenzija samopoštovanja, samosviđanja i samokompetentnosti, posebno tzv. paradoksalno samopoštovanje, o čemu će biti više riječi kasnije. Me- 
DRUŠ. ISTRAŽ. ZAGREB GOD. 21 (2012), BR. 2 (116)

STR. $443-463$

JELIĆ, M.: NOVE SPOZNAJE.. đutim, važno je napomenuti da dva navedena aspekta samopoštovanja nisu potpuno nezavisna, nego se među njima redovito dobiva umjerena pozitivna povezanost (Tafarodi i $\mathrm{Vu}$, 1997.; Tafarodi i sur., 2001.; Tafarodi i sur., 2003.). To ne iznenađuje, jer su kompetentni pojedinci obično bolje prihvaćeni, a pojedinci koji se sviđaju sami sebi i dobivaju potvrdu od socijalne okoline imaju više samopouzdanja u ostvarivanju vlastitih ciljeva u socijalnom kontekstu. Vjerojatno je upravo ta veza razlogom što je velik broj analiza skala samopoštovanja rezultirao faktorom višeg reda i potvrđuje samopoštovanje kao unidimenzionalan konstrukt.

Dakle, $\mathrm{s}$ jedne strane mnogo nalaza govori u prilog multidimenzionalne strukture samopoštovanja, no s druge strane neki autori ističu nezamjenjivost globalne mjere samopoštovanja. Tako Kernis (2003.) navodi da specifične samoevaluacije mogu biti dobri prediktori globalnoga samopoštovanja isključivo onda kada se odnose na centralne aspekte samopoimanja pojedinca te da i tada čak do $50 \%$ ukupne varijance općega samopoštovanja ostaje neobjašnjeno. Smatramo kako bi ovu polemiku trebalo rješavati zasebno za svako pojedino istraživanje, a ne tražeći opće načelo koje bi vrijedilo u svakoj situaciji. Čak se i Rosenberg (1969.) istodobno zalagao za upotrebu mjere globalnoga samopoštovanja i za usmjeravanje na pojedine aspekte samopoštovanja koji čine cjelinu. Po njegovu mišljenju, treba zasebno proučavati i samopoštovanje vezano uz domene i globalno samopoštovanje. Slažemo se s takvim razmišljanjem i vjerujemo kako bi odabir skale samopoštovanja $\mathrm{u}$ smislu njezine specifičnosti trebao ovisiti $\mathrm{u}$ prvom redu o cilju istraživanja. U istraživanjima je važno zahvatiti onaj aspekt samopoštovanja na koji se odnosi primijenjeni tretman koji se želi evaluirati ili pak aspekt samopoštovanja na koji bi trebala djelovati eksperimentalna manipulacija.

\section{RAZINA SAMOPOŠTOVANJA}

Razina samopoštovanja, definirana kao pozitivne i negativne evaluacije i osjećaji prema sebi, jedna je od najistraživanijih varijabli u istraživanjima ličnosti. U većini teorija i pristupa spominje se kao glavni stup adaptacije. Međutim, postoje dva problema vezana uz razinu samopoštovanja.

Prvo, iako se razina samopoštovanja zaista pokazala važnim korelatom brojnih fenomena s područja ljudskoga ponašanja, međukulturna istraživanja pokazala su da je distribucija samopoštovanja u populaciji pomaknuta prema višim vrijednostima (Schmitt i Allik, 2005.). Tako umjetna, statistička podjela na visoko i nisko samopoštovanje, koja se rabi u istraživanjima, nije sasvim opravdana. Naime, nisko samopoštovanje 
DRUŠ. ISTRAŽ. ZAGREB GOD. 21 (2012)

BR. 2 (116)

STR. $443-463$

JELIĆ, $M$.

NOVE SPOZNAJE... pulacija, ali rijetko kod studenata, koji su najčešća populacija $\mathrm{u}$ istraživanjima samopoštovanja. Ipak, niskim samopoštovanjem često se proglašava umjereno samopoštovanje koje odgovara srednjoj vrijednosti na skali samopoštovanja. Drugim riječima, u većini istraživanja pod pojmom "nisko samopoštovanje" zapravo se misli na osobe koje su pomalo nesigurne u svoj pojam o sebi. To potvrđuju i istraživanja koja su pokazala da je nisko samopoštovanje povezano s manjom jasnoćom slike o sebi (Campbell i sur., 1996., prema Kernis, 2003.). Poznato je i to da osobe tzv. niskoga samopoštovanja imaju i neke pozitivne stavove o sebi (Pelham, 1991., prema Kernis, 2003.). Ti nalazi čine pitanje razlike između visokoga i niskoga samopoštovanja manje kritičnim - $\mathrm{u}$ smislu da je razlika zapravo u razini samopoštovanja, a ne u vrstama samopoštovanja.

Drugi problem odnosi se na nalaze o visokom samopoštovanju. Naime, istraživanja redovito ističu pozitivne posljedice visokoga samopoštovanja. Specifično, pojedinci visokoga samopoštovanja bolje se nose s neuspjehom u usporedbi s pojedincima niskoga samopoštovanja (DiPaula i Campbell, 2002.; Baumeister i sur., 2003.). Nadalje, osobe višega samopoštovanja općenito se osjećaju sretnijima u životu (Diener i Diener, 1995.; DeNeve i Cooper, 1998.; Fumham i Cheng, 2000.; Shackelford, 2001.). Konačno, istraživanja su pokazala da visoko samopoštovanje ublažava anksioznost (Greenberg i sur., 1992.) i predviđa orijentaciju prema cilju i samoefikasnost kod studenata (Ang i sur., 2006.). Većina istraživanja provedenih kod nas usmjerena je na akademski kontekst i potvrđuju da je samopoštovanje prediktor školskog uspjeha i prilagodbe studiju (Lacković-Grgin i Sorić, 1997.; Rijavec i sur., 1999.). Novija istraživanja posebno upućuju na važnost povratne informacije za razvoj samopoštovanja na raznim područjima (Brajša-Žganec i sur., 2000.), pokazujući, primjerice, da pohvaljeni učenici imaju više samopoštovanje od nepohvaljenih i opominjanih (Smojver-Ažić i sur., 2005.). Osim pozitivnih učinaka visokoga samopoštovanja, istraživanja su pokazala i to da nisko samopoštovanje dovodi do nekih negativnih pojava, poput delinkventnoga ponašanja (Baumeister i DeWall, 2005.), neprimjerena ponašanja kod studenata (Ang i sur., 2006.), depresije (Whisman i Kwon, 1993.), bulimije (Button i sur., 1996.; Bulik i sur., 2001.) te sklonosti psihičkim bolestima (Roberts i Monroe, 1994.; Bardone i sur., 2000.; sve prema DeHart i sur., 2006.) i nezadovoljstvu vezama (Swann i sur., 1992.; Murray i sur., 2000.; DeHart i sur., 2003.; sve prema DeHart i sur., 2006.). To potvrđuju i istraživanja provedena kod nas, koja su pokazala da je samopoštovanje negativno povezano sa samoopterećivanjem (engl. self-handicapping; Burušić i Brajša-Žganec, 2005.), perfekcionizmom (Kolić-Vehovec, 2003.), osamljenošću (Lacković-Grgin i sur., 1998.), zlostavljanjem u djetinjstvu (Ćosić i sur., 2002.) 
DRUŠ. ISTRAŽ. ZAGREB GOD. 21 (2012), BR. 2 (116)

STR. $443-463$

JELIĆ, M.: NOVE SPOZNAJE.. te strahom od negativne evaluacije (Radovanovići Glavak, 2003.), kao i da postoji veza između samopoimanja i samopoštovanja te depresije (Stamać Ožanić, 2007.). Nalazi istraživanja koji upućuju na zaključak da je nisko samopoštovanje u jezgri mnogih problema u zadnje su vrijeme doveli do toga da se (prije svega u SAD-u) radi na podizanju samopoštovanja kod djece kao preventivne strategije kojom se nastoji prevenirati delinkventno, agresivno i pretjerano sramežljivo ponašanje djece i mladih. Visoko samopoštovanje smatra se poželjnom osobinom koju treba razvijati što ranije jer pojedincu donosi brojne psihološke dobrobiti.

Međutim, noviji nalazi koji rabe razinu samopoštovanja kao prediktorsku varijablu često su kontradiktorni i upućuju na zaključak da visoko samopoštovanje uopće nije jamstvo zadovoljstva životom te da je povezano s nizom problematičnih ponašanja i pristranosti u kognitivnom procesiranju. Tako se npr. pokazalo da je visoko samopoštovanje, između ostalog, povezano i sa samoopterećivanjem, agresivnosti (Baumeister i sur., 1996.), predrasudama (Crocker i sur., 1987.; Verkuyten, 1996.), diskriminacijom (posebno onih koji predstavljaju prijetnju slici o sebi), narcizmom, sklonosti pojedinca obrambenim reakcijama (Kernis i sur., 1993.; Kernis i Goldman, 2002.; Jordan i sur., 2005.) i nizom drugih pristranosti (Blaine i Crocker, 1993.; Gibbons i McCoy, 1991.; Tice, 1991.; Kernis, 2003.). Neka istraživanja provedena kod nas također su pokazala da visoko samopoštovanje može imati nepoželjne učinke - na primjer, da može biti prediktor pristranosti i diskriminacije $u$ međugrupnim odnosima (Jelić, 2003.). To dovodi u pitanje pretpostavku da se radi o adaptivnoj karakteristici. Zašto bi ljudi zadovoljni sobom imali potrebu za takvim pristranostima u percepciji i ponašanju?

Donedavno je većina autora smatrala kako su razne strategije i pristranosti kojima se služe osobe visokoga samopoštovanja nešto što je ključno kako bi to samopoštovanje održale, uzdigle ili vratile na zadovoljavajuću razinu i da su samim time nedjeljivo povezane s visokim samopoštovanjem. Temeljno visoko samopoštovanje daje im sigurnost da se upuste $\mathrm{u}$ ponašanja koja mogu biti nepoželjna ili ugrožavati druge ljude. Tako se, na primjer, pokazalo da smo skloni reagirati obrambeno, pa čak i agresivno, kad nam je ugrožen ego, i to posebno ako imamo moć (npr. šef u nekoj tvrtki), a osobno se osjećamo nekompetentnima (Fast i Chen, 2009.). Međutim, slažemo se s novijim objašnjenjima, po kojima je uporaba takvih pristranosti zapravo odraz nesigurnosti samopoštovanja (Kernis, 2003.). Tomu u prilog govori i činjenica da nisu svi ljudi visokoga samopoštovanja skloni pristranostima i obrambenim mehanizmima, odnosno da se može imati visoko samopoštovanje bez takvih obrambenih reakcija na prijetnju. 


\section{SIGURNOST SAMOPOŠTOVANJA}

Dosadašnja istraživanja upućuju na kvalitativno različite oblike visokoga samopoštovanja. Teoretičari samopoštovanja smatraju kako su neki pojedinci visokoga samopoštovanja posebno skloni obrambenim reakcijama i pristranostima u procesiranju, jer istodobno imaju dva kontradiktorna stava o sebi: na eksplicitnoj razini pozitivan stav, a na manje svjesnoj, implicitnoj, negativan stav o sebi. U novijoj literaturi to se naziva dvojnim stavovima (Wilson i sur., 2000.). Suvremeni teoretičari (Deci i Ryan, 1995.; Kernis, 2003.) smatraju da zapravo postoje dva oblika visokoga samopoštovanja: sigurno i krhko. Jedan noviji model, koji uspješno nastoji objasniti kontradiktorne nalaze o visokom samopoštovanju, jest tzv. model ugroženog egoizma (Kernis, 2000.). Po Kernisovu mišljenju, visoko, ali krhko, samopoštovanje (engl. fragile self-esteem) koje je lako ugroziti, često izaziva najizraženije obrambene reakcije i najviše pristranosti u procesiranju kako bi se to samopoštovanje održalo visokim. Često ga se još naziva i obrambenim samopoštovanjem. Drugim riječima, ovdje govorimo ne samo o razini nego i o sigurnosti samopoštovanja, kao važnoj odrednici ponašanja.

Ideja o obrambenom ili nesigurnom samopoštovanju nalazi potvrdu u kliničkoj praksi, koja nudi mnogo primjera uspješnih pojedinaca koji iza vrlo pozitivnog eksplicitnog, odnosno javno iskazanog, stava o sebi kriju osjećaj neadekvatnosti i sumnju u sebe. Ta sumnja i neadekvatnost mogu u situaciji prijetnje samopoštovanju aktivirati obrambene reakcije kako bi se ponovo uspostavio pozitivan stav o sebi. Nadalje, dosadašnja istraživanja potvrđuju da visoko samopoštovanje može imati siguran, ali i obrambeni, oblik. Kernis i suradnici (Kernis i Goldman, 2002.; Kernis, 2003.) pokazali su da se osobe nestabilnoga visokog samopoštovanja ponašaju kao da je njihovo samopoštovanje stalno $\mathrm{u}$ pitanju te loše podnose kritiku, imaju obrambeni stav u interakciji s drugima, pokazuju više razine ljutnje i neprijateljstva te su jako selektivne u prihvaćanju povratne informacije. Nadalje, više se hvale prijateljima svojim uspjesima, koristeći se pritom samouveličavanjem i više se samoopterećuju.

U literaturi se mogu naći tri modela za razlikovanje sigurnoga i krhkoga ili obrambenoga visokog samopoštovanja: 1. stabilnost samopoštovanja, 2. kontingentnost samopoštovanja, 3. različite razine implicitnoga i eksplicitnoga samopoštovanja. Kratko ćemo se osvrnuti na svaki od navedenih modela.

\section{STABILNOST SAMOPOŠTOVANJA}

Pojam stabilnosti samopoštovanja odnosi se na vremenske fluktuacije u samopoštovanju kao stanju i operacionalizira se kao varijabilitet globalnoga osobnog samopoštovanja u relativno kratkom vremenu. 
DRUŠ. ISTRAŽ. ZAGREB GOD. 21 (2012), BR. 2 (116)

STR. $443-463$

JELIĆ, M.:

NOVE SPOZNAJE..
Samopoštovanje se obično tretira kao stabilna karakteristika pojedinca, koja se, jednom formirana, teško može promijeniti. Ova je perspektiva bliska većini istraživača s ovoga područja jer omogućuje povezivanje samopoštovanja s raznim (adekvatnim i neadekvatnim) oblicima ponašanja i doživljavanja. Mnogi autori, kao i skale samopoštovanja, temelje se na ideji o samopoštovanju kao stabilnoj karakteristici (Rosenberg, 1965.; Fleming i Courtney, 1984.; Trzesniewski i sur., 2003.) i uglavnom ispituju samopoštovanje kao korelat nekih drugih psiholoških varijabli. To potvrđuju i nalazi nekih novijih istraživanja i metaanaliza koji su pokazali da su korelacije ponovljenih mjera samopoštovanja relativno visoke $(0,50-0,70)$ i usporedive sa stabilnosti osobina ličnosti (Trzesniewski i sur., 2003.). Pri tome se samopoštovanje pokazalo najmanje stabilnim tijekom djetinjstva, nešto stabilnijim u adolescenciji i ranoj odrasloj dobi te ponovo relativno nestabilnim u srednjoj i starijoj dobi (Trzesniewski i sur., 2003.), i to neovisno o spolu, etničkoj pripadnosti, nacionalnosti ili primijenjenoj mjeri samopoštovanja.

Međutim, kada samopoštovanje opisujemo stabilnom karakteristikom ličnosti svakoga pojedinca, velik problem predstavlja priroda promjena u samopoštovanju, do kojih dolazi zbog eksperimentalne manipulacije. Naime, uputom se može ugroziti samopoštovanje pojedinca, što može izazvati neke obrambene reakcije kako bi se samopoštovanje održalo ili uzdiglo. Dakle, ako je moguće samom uputom ili povratnom informacijom izazvati promjenu u razini samopoštovanja, nameće se pitanje je li zaista riječ o crti ličnosti ili ipak o trenutačnom stanju pojedinca.

Skloni smo se složiti s nekim suvremenim autorima koji smatraju kako je samopoštovanje relativno trajna karakteristika. Iako je samopoštovanje pojedinca podložno manjim promjenama u razini zbog npr. prijetnje samopoštovanju, dugoročno gledano svaki pojedinac ima svoju karakterističnu razinu samopoštovanja. Pri tome vjerujemo da je stabilnost razine samopoštovanja također varijabla po kojoj se pojedinci mogu razlikovati. Drugim riječima, kod nekih će pojedinaca karakteristična razina samopoštovanja varirati više, a kod drugih manje.

Novija istraživanja upućuju na zaključak da je stupanj stabilnosti samopoštovanja tijekom vremena, uz prosječnu razinu samopoštovanja, važna odrednica individualnih razlika u ponašanju i reakcijama na prijetnju samopoštovanju (Kernis i sur., 1991.; Kernis i sur., 1993.; Greenier i sur., 1995.). Problemom obrambenoga samopoštovanja posebno se bavio Kernis sa suradnicima (1993.) te utvrdio da je razlika u stabilnosti samopoštovanja povezana s obrambenosti, $\mathrm{tj}$. da je nestabilno visoko samopoštovanje obrambenijega karaktera od stabilnoga 
DRUŠ. ISTRAŽ. ZAGREB GOD. 21 (2012)

BR. 2 (116),

STR. $443-463$

JELIĆ, $M$.

NOVE SPOZNAJE.. samopoštovanja. Kernis je također utvrdio da je razina samopoštovanja izvrstan prediktor depresije, ali samo kod ljudi čije je samopoštovanje stabilno (Kernis i sur., 1991.). Kernis (2003.) smatra da je samopoštovanje nestabilno kada pozitivna slika o sebi zapravo skriva manje svjesnu sumnju u sebe, koja se katkad iskazuje u kontekstu neuspjeha. Tada se javljaju obrane kako bi se ponovo osnažila pozitivna slika o sebi.

Treba još spomenuti da se u novije vrijeme javljaju i drugačije operacionalizacije stabilnosti samopoštovanja, primjerice pomoću apstraktnosti samopoimanja (Updegraff i sur., 2010.). Radi se o stupnju u kojem ljudi konstruiraju važne temelje svojega samopoštovanja na širok, fleksibilan i apstraktan način (a ne na konkretan i specifičan način). Tako utemeljeno samopoštovanje manje varira zbog dnevnih događaja ili osjećaja, odnosno stabilnije je.

\section{KONTINGENTNOST (ZAVISNOST) SAMOPOŠTOVANJA}

Teoretičari i istraživači samopoštovanja u novije vrijeme ističu da se pojedinci razlikuju po stupnju na kojem njihovo samopoštovanje općenito ovisi o ishodima (Deci i Ryan, 1995.; Kernis, 2003.). Međutim, dok neki smatraju da je samopoštovanje svih ljudi ovisno o ishodima na jednom području - na primjer, na području socijalne prihvaćenosti, kao što tvrdi Leary (Leary i Baumeister, 2000.) - drugi ističu da samopoštovanje može biti ovisno o ishodima na raznim specifičnim područjima (Crocker i Wolfe, 2001.). Ta polemika zapravo prati pitanje jednodimenzionalnosti ili višedimenzionalnosti samopoštovanja.

Pojam zavisnoga samopoštovanja označuje upravo variranje samopoštovanja, ovisno o događajima, odnosno ishodima na područjima koja su nam važna. Iako je sam pojam novijega datuma, temelji se na Jamesovu shvaćanju samopoimanja, prema kojem ishodi na pojedinom specifičnom području utječu na samopoimanje i samopoštovanje pojedinca kada je riječ o području koje mu je važno i u koje je uključen, jer tada ovisi o uspjehu i neuspjehu postignutom na tom području (Crocker i sur., 2003.; Crocker i Wolfe, 2001.). Variranje u razini samopoštovanja bit će veće nakon pozitivnih ili negativnih ishoda na područjima koja su pojedincu važna u usporedbi s takvim ishodima na područjima nevažnim za samopoštovanje. Moguć uzrok tomu jest i to što se upravo rezultati koje pojedinac postiže na tim područjima (o kojima je samopoštovanje zavisno) generaliziraju na vrijednost cijele osobe. Istraživanja zavisnoga samopoštovanja obično su ograničena na nekoliko ključnih područja: akademsko samopoštovanje, fizički izgled, odobravanje drugih, odnosno socijalna prihvaćenost, te ljubav i podrška obitelji (Crocker i Wolfe, 2001.). 


\section{IMPLICITNO SAMOPOŠTOVANJE}

Budući da je danas, posebno u individualističkim kulturama, moderno, prihvaćeno i socijalno poželjno imati visoko samopoštovanje, odnosno djelovati samouvjereno i sigurno u vlastitu vrijednost, valja očekivati da će se to odraziti i na ispunjavanje skala samopoštovanja. Naime, prosječne razine samopoštovanja dobivene eksplicitnim mjerama samopoštovanja redovito su pomaknute prema višim vrijednostima, čemu uzrok možemo tražiti u socijalno poželjnom odgovaranju na tvrdnje u upitnicima i skalama samopoštovanja. Stoga se istraživači sve češće okreću traženju implicitnih mjera općega samopoštovanja kojima bi se taj problem mogao izbjeći.

U literaturi se mogu naći tri kriterija koja određenu mjeru čine implicitnom: a) sudionici nisu svjesni činjenice da se neki stav mjeri (Brunel i sur., 2004.), b) sudionici nemaju svjestan pristup tom stavu (Asendorpf i sur., 2002.), c) sudionici nemaju kontrolu nad ishodom mjerenja (Fazio i Olson, 2003., prema De Houwer, 2006.). Implicitne mjere dugo su se zasnivale na projektivnim testovima i jednostavnom vremenu latencije, no u novije vrijeme sve se više rabe: test implicitnih asocijacija (IAT; Greenwald i sur., 1998.), zadatak afektivnog udešavanja (engl. affective priming task; Fazio i sur., 1995.), Go-No Go Task (GNAT; Nosek i Banaji, 2001.) te ekstrinzični afektivni Simonov zadatak (engl. Extrinsic Affective Simon Task - EAST; De Houwer, 2003.). Osim tih "računalnih" mjera, rabe se i neki drugi načini mjerenja implicitnoga samopoštovanja, poput zadatka asocijacija na zadane riječi (engl. word association task; Stacy, 1997.), preferencijom za vlastite inicijale (engl. name letter effect; Koole i sur., 2001.; Pelham i sur., 2005.) ili preferencijom za brojeve datuma rođenja, a neki istraživači uzimaju i veličinu potpisa unutar zadanog okvira kao mjeru pozitivnosti stava o sebi (Stapel i Blanton, 2004.). U našoj zemlji, koliko nam je poznato, dosad se rabio samo IAT kao mjera implicitnoga samopoštovanja (Jelić i Tonković, 2009.).

Temeljna prednost implicitnih mjera samopoštovanja leži u činjenici da su nereaktivne, tj. da sudionici nisu ni svjesni da su evaluirani u trenutku kad npr. potpisuju svoje ime niti se od njih traži da daju neku procjenu o sebi. Upravo stoga istraživači vjeruju da takve mjere mogu dati realniju sliku o samom sudioniku, očišćenu od želje da se prikaže u najboljem svjetlu. Iako još uvijek vladaju polemike oko toga što zaista mjerimo implicitnim mjerama, sve je više istraživača koji ih rabe, kao i provjera valjanosti koje im govore u prilog (Bosson i sur., 2000.). Međukulturna istraživanja također daju potvrdu valjanosti implicitnih mjera samopoštovanja (Kurman, 2003.). 
DRUŠ. ISTRAŽ. ZAGREB GOD. 21 (2012)

BR. 2 (116)

STR. $443-463$

JELIĆ, $M$.

NOVE SPOZNAJE..
Zanimljivo je da se često dobivaju razne razine implicitnoga i eksplicitnoga općeg samopoštovanja, što je u skladu s idejom o sigurnom i krhkom samopoštovanju. To implicitne mjere čini posebno atraktivnima, jer one nude mogućnost razlikovanja "obrambenih" i "sigurnih" pojedinaca unutar jedne razine samopoštovanja i jasniji uvid u vezu između evaluacije sebe i reakcija na prijetnju samopoštovanju (Jordan i sur., 2005.). Nadalje, istraživanja koja su uzimala i implicitnu i eksplicitnu mjeru samopoštovanja pokazala su da je implicitno samopoštovanje bolji prediktor neverbalne anksioznosti (Spalding i Hardin, 1999., prema DeHart i sur., 2006.) i negativnoga raspoloženja (Greenwald i Farnham, 2000.) od eksplicitnoga samopoštovanja. Nadalje, implicitno samopoštovanje (ali ne i eksplicitno) predviđa pristranost u vlastitu korist te socijalno nepoželjna ponašanja nakon neuspjeha (Pelham i Hetts, 1999.). Konačno, kombinacija visokoga eksplicitnog i niskoga implicitnog samopoštovanja povezana je s višim narcizmom osobe (Bosson i Swann, 1998.; Bosson i sur., 2003.; Jordan i sur., 2003., sve prema DeHart i sur., 2006.; Zeigler-Hill, 2006.) te s brojnim pristranostima u procesiranju koje vode samouzdizanju (Bosson i sur., 2003.).

Smatramo kako sva tri navedena načina određivanja sigurnosti samopoštovanja mogu biti vrlo korisna jer produbljuju naše razumijevanje učinaka visokoga samopoštovanja. No gledano teorijski, mjerenje razina implicitnoga i eksplicitnoga samopoštovanja smatramo najopravdanijim, jer je upravo to razlika na koju se konstrukt sigurnosti samopoštovanja odnosi. Nadalje, prilikom mjerenja implicitnoga i eksplicitnoga samopoštovanja riječ je o općem samopoštovanju, dok se kod kontingentnoga samopoštovanja zbog prijetnje preusmjeravamo na drugo područje samopoštovanja. Kod stabilnosti postoji problem ponovljenih mjerenja istom skalom (postoji svijest o samom predmetu mjerenja kao i veća vjerojatnost socijalno poželjnih odgovora). No buduća istraživanja trebaju se usmjeriti prema poboljšanju mjerenja implicitnoga samopoštovanja, jer trenutačno na ovom području još ima dosta nejasnoća i kompleksnih pitanja s kojima se treba suočiti kako bismo mogli odrediti je li i kako implicitno samopoštovanje povezano s drugim konstruktima, poput sigurnoga ili optimalnoga samopoštovanja. Slažemo se s istraživačima koji cilj vide u stvaranju modela koji mogu objediniti sličnosti i razlike u eksplicitnim i implicitnim mjerama unutar jedinstvenoga procesnog okvira koji objašnjava i fenomenologiju (Krizan, 2008.).

\section{PARADOKSALNO SAMOPOŠTOVANJE}

Osim navedenih modela za razlikovanje sigurnoga i krhkoga samopoštovanja, smatramo važnim istaknuti još jedan konstrukt - paradoksalno samopoštovanje. Taj naziv označuje suprotstavljene razine dvaju različitih oblika ili domena samopo- 
DRUŠ. ISTRAŽ. ZAGREB GOD. 21 (2012),

BR. 2 (116)

STR. $443-463$

JELIĆ, M.:

NOVE SPOZNAJE.. štovanja i najčešće se rabi u kontekstu suprotnih razina samosviđanja i samokompetentnosti.

Iako su dimenzije samopoštovanja obično umjereno pozitivno korelirane (osobe visokoga samosviđanja obično imaju i visok rezultat na samokompetentnosti i obratno), postoji i druga mogućnost - da pojedinci imaju nizak rezultat na jednoj dimenziji, a ipak visok na drugoj. Tu mogućnost spominje još William James (1890./1950.), ističući kako je samopoštovanje pojedinca neovisno o objektivnim razlozima te osobe za zadovoljstvo ili nezadovoljstvo i navodeći primjere ljudi koji, usprkos velikom uspjehu na svim poljima djelovanja, ostaju nesigurni u vlastitu vrijednost, kao i onih koji uobraženo prolaze kroz život ne primjećujući i ne mareći za vlastite neuspjehe. Kako paradoksalno samopoštovanje zapravo znači izazov općeprihvaćenom uvjerenju da je samopoštovanje pojedinca određeno povratnom informacijom koju dobiva iz okoline, mnogi su se istraživači u novije vrijeme zainteresirali za povezanost paradoksalnoga samopoštovanja i selektivnoga pamćenja iskustava (Bruner, 1994.; Singer i Salovey, 1996.; Kihlstrom, 1997.; sve prema Tafarodi i sur., 2003.). Istraživanja pokazuju da pojedinci paradoksalno niskoga samosviđanja (dakle, ujedno visoke samokompetentnosti), usprkos svojoj uspješnosti, uz pomoć pristranosti pamćenja zadržavaju osjećaj vlastite bezvrijednosti i on ih čini osjetljivima i sklonima samookrivljavanju i razočaranju u svakoj situaciji u kojoj nisu uspjeli sasvim zadovoljiti vlastiti visoki standard učinkovitosti (Tafarodi i Vu, 1997.). Tafarodi i suradnici (2001.) također su pokazali da, iako pristranost pamćenja pridonosi održavanju paradoksalnoga samopoštovanja, kod tzv. paradoksalnih pojedinaca ipak u većoj mjeri nego kod neparadoksalnih dolazi do promjene u samosviđanju četiri mjeseca kasnije. Najnovija istraživanja nastoje utvrditi $u$ kakvoj su vezi paradoksalnost samopoštovanja i njegova stabilnost, odnosno imaju li paradoksalni pojedinci ujedno i nestabilnije samopoštovanje od neparadoksalnih. Zasad nema istraživanja koje bi ponudilo jednoznačan odgovor na to pitanje. Međutim, dodatnu potvrdu ideji da su upravo suprotstavljene razine samopoštovanja najjače povezane s pristranostima u procesiranju informacija i u ponašanju nude istraživanja koja su proučavala suprotstavljene razine osobnoga i socijalnoga samopoštovanja. Rezultati istraživanja provedenog u prirodnim uvjetima na dvije etničke skupine pokazuju da upravo pojedinci visokoga socijalnog i niskoga osobnog samopoštovanja pokazuju najviše pristranosti prema vlastitoj grupi i sklonost diskriminaciji druge grupe (Jelić, 2003.).

Smatramo kako bi paradoksalno samopoštovanje također trebalo tretirati kao način određivanja sigurnosti samopoštovanja. Stoga predlažemo da se u raniju klasifikaciju kao 
treći model uvede usklađenost samopoštovanja, jer taj naziv uključuje i različite razine eksplicitnoga i implicitnoga općeg samopoštovanja, ali i različite razine pojedinih područja samopoštovanja, odnosno paradoksalno samopoštovanje.

\section{SRODNI KONSTRUKTI}

Mnogi se autori bave konstruktom samopoštovanja, pa nije čudo što u literaturi ima mnogo naziva za vrlo slične ili srodne konstrukte, što dovodi do zabune i nejasnoća. Osim sigurnosti samopoštovanja, kojom smo se bavili i u ovom radu, u literaturi se nalaze i ponešto drugačiji nazivi i operacionalizacije koje ćemo kratko spomenuti i objasniti. Prije svega valja upozoriti na razliku između stabilnosti samopoštovanja, koja se obično operacionalizira kao varijabilitet globalnoga osobnog samopoštovanja u relativno kratkom vremenu, i konstrukta postojanosti samopoštovanja (engl. self-esteem certainty), koji se često prevodi kao stabilnost ili sigurnost samopoštovanja, ali se odnosi na samoiskazanu sigurnost vlastita samopoštovanja, odnosno na vlastitu percepciju toga koliko je naše samopoštovanje utvrđeno i postojano. Nazivi obrambeno samopoštovanje i krhko samopoštovanje obično označuju samopoštovanje podložno raznim pristranostima i obrambenim reakcijama kako bi se održalo, odnosno samopoštovanje koje je lako ugroziti i koje na prijetnju reagira vrlo obrambeno (za razliku od optimalnoga ili autentičnoga samopoštovanja). Nadalje, labilnost samopoštovanja odnosi se na mjeru u kojoj je samopoštovanje reaktivno na dnevne prijetnje i poticaje, a obično se određuje korelacijom dnevnoga samopoštovanja s dnevnim događajima (Butler i sur., 1994.).

\section{ZAKLJUČAK}

Pod pojmom samopoštovanje razumijevamo evaluaciju samoga sebe, u smislu stupnja prihvaćanja sebe onakvima kakvima se percipiramo na relevantnim dimenzijama. Pri tome razina samopoštovanja može varirati ovisno o dnevnim događajima ili životnim izazovima, a čak i visoko samopoštovanje može biti izrazito obrambenoga karaktera ako osoba na nesvjesnoj razini nosi duboko usađenu sumnju u sebe. Kontradiktorni nalazi vezani uz visoko samopoštovanje pokazuju da razina samopoštovanja ne može objasniti niz nepoželjnih i obrambenih reakcija koje se javljaju zbog prijetnje samopoštovanju.

Novija istraživanja upućuju na sigurnost samopoštovanja kao varijablu koja može pridonijeti boljem razumijevanju funkcije samopoštovanja, jer je sigurnost samopoštovanja pokazatelj njegove autentičnosti. Iako sigurnost i razina samopoštovanja nisu statistički nezavisne varijable (međusobno su 
DRUŠ. ISTRAŽ. ZAGREB GOD. 21 (2012), BR. 2 (116)

STR. $443-463$

JELIĆ, M.: NOVE SPOZNAJE..

\section{LITERATURA}

u niskoj pozitivnoj korelaciji), sigurnost ima i niz jedinstvenih korelata. Stoga smatramo kako bi podjela visokoga samopoštovanja na sigurno i nesigurno mogla razriješiti neke dvojbe unutar teorije samopoimanja i objasniti zbunjujuće nalaze koji se tiču korelata visokoga samopoštovanja. Sigurno samopoštovanje najčešće se operacionalizira kroz stabilnost samopoštovanja, iako su moguće i drugačije operacionalizacije (zavisnost samopoštovanja, usklađenost samopoštovanja).

Smatramo da su svi navedeni konstrukti put prema mjeri autentičnoga samopoštovanja, koju tek treba operacionalizirati. No do tada smatramo kako bi istraživači samopoštovanja trebali u skladu s novim spoznajama što preciznije odrediti koje i kakvo samopoštovanje žele mjeriti s obzirom na njegovu strukturu. Također sugeriramo istraživačima da konstrukt samopoštovanja zahvaćaju na više načina - koristeći se mjerom razine i mjerom sigurnosti samopoštovanja (jer upravo njihovo izjednačavanje dovodi do kontradiktornih nalaza koje je teško objasniti), kako bi njihovi nalazi zaista bili relevantni i ponudili jasniji uvid u ovaj važan i zanimljiv konstrukt, a ne pridonijeli postojećoj konfuziji u literaturi. Teorijski gledano, najopravdanijim smatramo mjerenje razina implicitnoga i eksplicitnoga samopoštovanja. No kako implicitne mjere još uvijek imaju brojne nedostatke te su često kompliciranije za provedbu, predlažemo i drugu mjeru usklađenosti samopoštovanja - paradoksalno samopoštovanje.

Ang, R. P., Neubronner, M., Oh, S. i Leong, V. (2006.), Dimensionality of Rosenberg's Self-Esteem Scale among Normal-Technical Stream Students in Singapore. Current Psychology, 25 (2): 121-131. doi:10.1007/ s12144-006-1007-3

Asendorpf, J. B., Banse, R. i Mucke, D. (2002.), Double Dissociation between Implicit and Explicit Personality Self-Concept: The Case of Shy Behaviour. Journal of Personality and Social Psychology, 83 (2): 380393. doi:10.1037/0022-3514.83.2.380

Bandura, A. (1992.), Exercise of Personal Agency through the Self-Efficacy Mechanism. U: R. Schwarzer (ur.), Self-Efficacy: Thought Control of Action (str. 3-38), Washington, D.C., Hemisphere.

Barber, B. K. i Thomas, D. L. (1986.), Dimensions of Adolescent Self-Esteem and Religious Self-Evaluation. Family Perspective, 20: 137-149.

Baumeister, R. F. i DeWall, C. N. (2005.), The Inner Dimension of Social Exclusion: Intelligent Thought and Self-Regulation among Rejected Persons. U: K. Williams, J. Forgas i W. Von Hippel (ur.), The Social Outcast: Ostracism, Social Exclusion, Rejection, and Bullying (str. 53-73), New York, Psychology Press.

Baumeister, R. F., Campbell, J. D., Krueger, J. I. i Vohs, K. D. (2003.), Does High Self-Esteem Cause Better Performance, Interpersonal Success, Happiness, or Healthier Lifestyles? Psychological Science in the Public Interest, 4 (1): 1-44. doi:10.1111/1529-1006.01431 
DRUŠ. ISTRAŽ. ZAGREB GOD. 21 (2012) BR. 2 (116),

STR. $443-463$

JELIĆ, M.: NOVE SPOZNAJE..
Baumeister, R. F., Smart, L. i Boden, J. M. (1996.), Relation of Threatened Egotism to Violence and Aggression: The Dark Side of High Self-Esteem. Psychological Review, 103 (1): 5-33. doi:10.1037/0033-295X. 103.1.5

Blaine, B. i Crocker, J. (1993.), Self-Esteem and Self-Serving Biases in Reactions to Positive and Negative Events: An Integrative Review. U: R. F. Baumeister (ur.), Self-Esteem: The Puzzle of Low Self-Regard (str. 55-85), Hillsdale, NJ, Erlbaum.

Bosson, J. K., Brown, R. P., Zeigler-Hill, V. i Swann, W. B., Jr. (2003.), Self-Enhancement Tendencies among People with High Explicit Self-Esteem: The Moderating Role of Implicit Self-Esteem. Self and Identity, 2 (3): 169-187. doi:10.1080/15298860309029

Bosson, J. K., Swann, W. B., Jr. i Pennebaker, J. W. (2000.), Stalking the Perfect Measure of Implicit Self-Esteem: The Blind Men and the Elephant Revisited? Journal of Personality and Social Psychology, 79 (4): 631-643. doi:10.1037/0022-3514.79.4.631

Brajša-Žganec, A., Raboteg-Šarić, Z. i Franc, R. (2000.), Dimenzije samopoimanja djece u odnosu na opaženu socijalnu podršku iz različitih izvora. Društvena istraživanja, 9 (6): 897-912.

Brunel, F. F., Tietje, B. C. i Greenwald, A. G. (2004.), Is the Implicit Association Test a Valid and Valuable Measure of Implicit Consumer Social Cognition? Journal of Consumer Psychology, 14 (4): 385-404. doi:10. 1207/s15327663jcp1404_8

Bulik, C. M., Wade, T. D. i Kendler, K. S. (2001.), Characteristics of Monozygotic Twins Discordant for Bulimia Nervosa. International Journal of Eating Disorders, 29 (1): 1-10. doi:10.1002/1098-108X(200101) 29:1<1::AID-EAT1>3.3.CO;2-A

Burušić, J. i Brajša-Žganec, A. (2005.), Odnos samohendikepiranja, samopoštovanja i jasnoće pojma o sebi. Psihologijske teme, 14 (1): 83-90.

Butler, A. C., Hokanson, J. E. i Flynn, H. A. (1994.), A Comparison of Self-Esteem Lability and Low Trait Self-Esteem as Vulnerability Factors for Depression. Journal of Personality and Social Psychology, 66 (1): 166-177. doi:10.1037/0022-3514.66.1.166

Button, E. J., Sonuga-Barke, E. J. S., Davies, J. i Thompson, M. (1996.), A Prospective Study of Self-Esteem in the Prediction of Eating Problems in Adolescent Schoolgirls: Questionnaire Findings. British Journal of Clinical Psychology, 35 (2): 193-203. doi:10.1111/j.2044-8260.1996. tb01176.x

Coopersmith, S. (1967.), The Antecedents of Self-Esteem, San Francisco, Freeman.

Crocker, J. i Wolfe, C. T. (2001.), Contingencies of Self-Worth. Psychological Review, 108 (3): 593-623. doi:10.1037/0033-295X.108.3.593

Crocker, J., Thompson, L., McGraw, K. i Ingerman, C. (1987.), Downward Comparison, Prejudice, and Evaluation of Others: Effects of Self-Esteem and Threat. Journal of Personality and Social Psychology, 52 (5): 907-916. doi:10.1037/0022-3514.52.5.907

Crocker, J., Luhtanen, R. K., Cooper, M. L. i Bouvrette, S. (2003.), Contingencies of Self-Worth in College Students: Theory and Measurement. Journal of Personality and Social Psychology, 85 (5): 894-908. doi:10. 1037/0022-3514.85.5.894 
DRUŠ. ISTRAŽ. ZAGREB GOD. 21 (2012), BR. 2 (116)

STR. $443-463$

JELIĆ, M.: NOVE SPOZNAJE..
Ćosić, I., Buljan-Flander, G. i Karlović, A. (2002.), Povezanost zlostavljanja u djetinjstvu i nekih aspekata psihičkog funkcioniranja adolescenata. Suvremena psihologija, 5 (2): 191-205.

De Houwer, J. (2006.), What Are Implicit Measures and Why Are We Using Them? U: R. W. Wiers and A. W. Stacy (ur.), Handbook of Implicit Cognition and Addiction (str. 11-28), Thousand Oaks, CA, Sage.

De Houwer, J. (2003.), The Extrinsic Affective Simon Task. Experimental Psychology, 50 (2): 77-85.

Deci, E. L. i Ryan, R. M. (1995.), Self-Determination Theory, New York, Plenum Press.

DeHart, T., Pelham, B. W. i Tennen, H. (2006.), What Lies Beneath: Parenting Style and Implicit Self-Esteem. Journal of Experimental Social Psychology, 42 (1): 1-17. doi:10.1016/j.jesp.2004.12.005

DeNeve, K. M. i Cooper, H. (1998.), The Happy Personality: A Meta-Analysis of 137 Personality Traits and Subjective Well-Being. Psychological Bulletin, 124 (2): 197-229. doi:10.1037/0033-2909.124.2.197

Diener, E. i Diener, M. (1995.), Cross-Cultural Correlates of Life Satisfaction and Self-Esteem. Journal of Personality and Social Psychology, 68 (4): 653-663. doi:10.1037/0022-3514.68.4.653

DiPaula, A. i Campbell, J. D. (2002.), Self-Esteem and Persistence in the Face of Failure. Journal of Personality and Social Psychology, 83 (3): 711-724. doi:10.1037/0022-3514.83.3.711

Fast, N. J. i Chen, S. (2009.) When the Boss Feels Inadequate: Power, Incompetence, and Aggression. Psychological Science, 20 (11): 1406-1413. doi:10.1111/j.1467-9280.2009.02452.x

Fazio, R. H., Jackson, J. R., Dunton, B. C. i Williams, C. J. (1995.), Variability in Automatic Activation as an Unobtrusive Measure of Racial Attitudes: A Bona Fide Pipeline? Journal of Personality and Social Psychology, 69 (6): 1013-1027. doi:10.1037/0022-3514.69.6.1013

Fitts, P. M. (1964.), Perceptual-Motor Skill Learning. U: A. W. Melton (ur.), Categories of Human Learning, New York, NY, Academic Press.

Fleming, J. S. i Courtney, B. E. (1984.), The Dimensionality of Self-Esteem: II. Hierarchical Facet Models for Revised Measurement Scales. Journal of Personality and Social Psychology, 46 (2): 404-421. doi:10.1037// 0022-3514.46.2.404

Franks, D. D. i Marolla, J. (1976.), Efficacious Action and Social Approval as Interacting Dimensions of Self-Esteem: A Tentative Formulation through Construct Validation. Sociometry, 39 (4): 324-341. doi:10.2307/3033498

Fumham, A. i Cheng, H. (2000.), Lay Theories of Happiness. Journal of Happiness Studies, 1 (2): 227-246.

Gecas, V. i Schwalbe, M. L. (1986.), Parental Behavior and Adolescent Self-Esteem. Journal of Marriage and Family, 48: 37-46.

Gibbons, F. X. i McCoy, S. B. (1991.), Self-Esteem, Similarity, and Reactions to Active Versus Passive Downward Comparison. Journal of Personality and Social Psychology, 60 (3): 414-424. doi:10.1037/0022-3514. 60.3.414 
DRUŠ. ISTRAŽ. ZAGREB GOD. 21 (2012) BR. 2 (116),

STR. $443-463$

JELIĆ, M. NOVE SPOZNAJE..
Greenberg, J., Solomon, S., Pyszczynski, T., Rosenblatt, A., Burling, J., Lyon, D., Simon, L. i Pinel, E. (1992.), Why Do People Need Self-Esteem? Converging Evidence that Self-Esteem Serves an Anxiety-Buffering Function. Journal of Personality and Social Psychology, 63 (6): 913-922.

Greenier, K. D., Kernis, M. H. i Waschull, S. B. (1995.), Not All High (or Low) Self-Esteem People are the Same: Theory and Research on Stability of Self-Esteem. U: M. H. Kernis (ur.), Efficacy, Agency, and Self-Esteem (str. 51-68), New York, Plenum Press.

Greenwald, A. G. i Farnham, S. D. (2000.), Using the Implicit Association Test to Measure Self-Esteem and Self-Concept. Journal of Personality and Social Psychology, 79 (6): 1022-1038. doi:10.1037/00223514.79.6.1022

Greenwald, A. G., McGhee, D. E. i Schwartz, J. K. L. (1998.), Measuring Individual Differences in Implicit Cognition: The Implicit Association Test. Journal of Personality and Social Psychology, 74 (6): 1464-1480. doi:10.1037/0022-3514.74.6.1464

Harter, S. (1985.), Competence as a Dimension of Self-Evaluation: Toward a Comprehensive Model of Self-Worth. U: R. L. Leahy (ur.), The Development of the Self, Orlando, FL, Academic Press.

Harter, S. (1999.), The Construction of the Self: A Developmental Perspective, New York, Guilford.

James, W. (1890./1950.), The Principles of Psychology, Dover, New York. (Original work published 1890.)

Janis, I. L. i Field, P. B. (1959.), Sex Differences and Factors Related to Persuasibility. U: C. I. Hovland i I. L. Janis (ur.), Personality and Persuasibility, New Haven, CT, Yale University Press.

Jelić, M. (2003.), Provjera postavki teorije socijalnog identiteta na etničkim grupama, Magistarski rad, Odsjek za psihologiju, Filozofski fakultet, Zagreb.

Jelić, M. i Tonković, M. (2009.), Test implicitnih asocijacija u ispitivanju samopoštovanja. Psihologijske teme, 18 (1): 183-201.

Jordan, C. H., Spencer, S. J. i Zanna, M. P. (2005.), Types of High Self-Esteem and Prejudice: How Implicit Self-Esteem Relates to Ethnic Discrimination among High Explicit Self-Esteem Individuals. Personality and Social Psychology Bulletin, 31 (5): 693-702. doi:10.1177/014 6167204271580

Kernis, M. H. (2000.), Substitute Needs and Fragile Self-Esteem. Psychological Inquiry, 11: 298-300.

Kernis, M. H. i Goldman, B. M. (2002.), Stability and Variability in Self-Concept and Self-Esteem. U: M. Leary i J. Tangney (ur.), Handbook of Self and Identity (str. 106-127), New York, Guilford Press.

Kernis, M. H., Cornell, D. P., Sun, C. R., Berry, A. J. i Harlow, T. (1993.), There's More to Self-Esteem than Whether it is High or Low: The Importance of Stability of Self-Esteem. Journal of Personality and Social Psychology, 65 (6): 1190-1204. doi:10.1037/0022-3514.65.6.1190

Kernis, M. H., Grannemann, B. D. i Mathis, L. C. (1991.), Stability of Self-Esteem as a Moderator of the Relation between Level of Self-Esteem and Depression. Journal of Personality and Social Psychology, 61 (1): 80-84. doi:10.1037/0022-3514.61.1.80 
DRUŠ. ISTRAŽ. ZAGREB GOD. 21 (2012), BR. 2 (116)

STR. $443-463$

JELIĆ, M.: NOVE SPOZNAJE..
Kernis, M. H. (2003.), Toward a Conceptualization of Optimal Self-Esteem. Psychological Inquiry, 14 (1): 1-26 doi:10.1207/S15327965PLI 1401_01

Kolić-Vehovec, S. (2003.), Perfekcionizam, ispitna anksioznost i akademsko samopoimanje darovitih gimnazijalaca. Društvena istraživanja, 12 (5): 679-702.

Koole, S. L., Dijksterhuis, A. i van Knippenberg, A. (2001.), What's in a Name: Implicit Self-Esteem and the Automatic Self. Journal of Personality and Social Psychology, 80 (4): 669-685. doi:10.1037/0022-3514. 80.4.669

Krizan, Z. (2008.), What is Implicit about Implicit Self-Esteem? Journal of Research in Personality, 42 (6): 1635-1640. doi:10.1016/j.jrp.2008. 07.002

Kurman, J. (2003.), Why is Self-Enhancement Low in Certain Collectivist Cultures? An Investigation of Two Competing Explanations. Journal of Cross-Cultural Psychology, 34 (5): 496-510. doi:10.1177/0022 022103256474

Lacković-Grgin, K. i Sorić, I. (1997.), Korelati prilagodbe studiju tijekom prve godine. Društvena istraživanja, 6 (4-5): 461-475.

Lacković-Grgin, K., Penezić, Z. i Sorić, I. (1998.), Usamljenost i samoća studenata: uloga afilijativne motivacije i nekih osobnih značajki. Društvena istraživanja, 7 (4-5): 543-558.

Leary, M. R. i Baumeister, R. F. (2000.), The Nature and Function of Self-Esteem: Sociometer Theory. U: M. Zanna (ur.), Advances in Experimental Social Psychology (Vol. 32, str. 1-62), San Diego, CA, Academic Press.

Nosek, B. A. i Banaji, M. R. (2001.), The Go/No-Go Association Task. Social Cognition, 19 (6): 625-666. doi:10.1521/soco.19.6.625.20886

Openshaw, D. K., Thomas, D. L. i Rollins, B. C. (1981.), Adolescent Self-Esteem: A Multidimensional Perspective. Journal of Early Adolescence, 1 (3): 273-282. doi:10.1177/027243168100100306

Pelham, B. W. i Hetts, J. J. (1999.), Implicit and Explicit Personal and Social Identity: Toward a More Complete Understanding of the Social Self. U: T. Tyler, R. Kramer and O. John (ur.), The Psychology of the Social Self, Erlbaum, New York.

Pelham, B. W., Koole, S. L., Hardin, C. D., Hetts, J. J., Seah, E. i DeHart, T. (2005.), Gender Moderates the Relation between Implicit and Explicit Self-Esteem. Journal of Experimental Social Psychology, 41 (1): 84-89. doi:10.1016/j.jesp.2003.10.008

Radovanović, N. i Glavak, R. (2003.), Povezanost straha od negativne evaluacije sa samopoimanjem i socijalnom percepcijom kod adolescenata. Društvena istraživanja, 12 (6): 1123-1139.

Rijavec, M., Raboteg-Šarić, Z. i Franc, R. (1999.), Komponente samoreguliranog učenja i školski uspjeh. Društvena istraživanja, 8 (4): 529-541.

Rosenberg, M. (1965.), Society and the Adolescent Self-Image, Princeton, NJ, Princeton University Press.

Rosenberg, M. J. (1969.), The Conditions and Consequences of Evaluation Apprehension. U: R. Rosenthal i R. L. Rosnow (ur.), Artifact in Behavioral Research (str. 279-349), New York, Academic Press. 
DRUŠ. ISTRAŽ. ZAGREB GOD. 21 (2012) BR. 2 (116),

STR. $443-463$

JELIĆ, M.: NOVE SPOZNAJE..
Rubin, M. i Hewstone, M. (1998.), Social Identity Theory's Self-Esteem Hypothesis: A Review and Some Suggestions for Clarification. Personality and Social Psychology Review, 2 (1): 40-62. doi:10.1207/s15 327957pspr0201_3

Schmitt, D. P. i Allik, J. (2005.), Simultaneous Administration of the Rosenberg Self-Esteem Scale in 53 Nations: Exploring the Universal and Culture-Specific Features of Global Self-Esteem. Journal of Personality and Social Psychology, 89 (4): 623-642. doi:10.1037/0022-3514. 89.4.623

Shackelford, T. K. (2001.), Self-Esteem in Marriage. Personality and Individual Differences, 30 (3): 371-390. doi:10.1016/S0191-8869(00)000 23-4

Shavelson, R. J., Hubner, J. T. i Staton, G. C. (1976.), Self-Concept: Validation of Construct Interpretation. Review of Educational Research, 46 (3): 407-441. doi:10.3102/00346543046003407

Smojver-Ažić, S., Rački, Ž. i Živčić-Bećirević, I. (2005.), Problemi u ponašanju i osobine ličnosti opomenutih i pohvaljenih učenika. Napredak, 146 (1): 5-16.

Stacy, A. W. (1997.), Memory Activation and Expectancy as Prospective Predictors of Alcohol and Marijuana Use. Journal of Abnormal Psychology, 106 (1): 61-73. doi:10.1037/0021-843X.106.1.61

Stamać Ožanić, M. (2007.), Neusklađeni pojam o sebi kao osnova za sklonost depresivnosti ili samohendikepiranju osoba s neadaptionim atribucijskim stilom, Neobjavljeni magistarski rad, Zagreb, Odsjek za psihologiju Filozofskog fakulteta u Zagrebu.

Stapel, D. A. i Blanton, H. (2004.), From Seeing to Being: Subliminal Social Comparisons Affect Implicit and Explicit Self-Evaluations. Journal of Personality and Social Psychology, 87 (4): 468-481. doi:10.1037/00223514.87.4.468

Tafarodi, R. W. i Vu, C. (1997.), Two-Dimensional Self-Esteem and Reactions to Success and Failure. Personality and Social Psychology Bulletin, 23 (6): 626-635. doi:10.1177/0146167297236006

Tafarodi, R. W. i Milne, A. B. (2002.), Decomposing Global Self-Esteem. Journal of Personality, 70 (4): 443-484. doi:10.1111/1467-6494.05017

Tafarodi, R. W. i Swann, W. B. (1995.), Self-Liking and Self-Competence as Dimensions of Global Self-Esteem: Initial Validation of a Measure. Journal of Personality Assessment, 65 (2): 322-342. doi:10. 1207/s15327752jpa6502_8

Tafarodi, R. W., Marshall, T. C. i Milne, A. B. (2003.), Self-Esteem and Memory. Journal of Personality and Social Psychology, 84 (1): 29-45. doi:10.1037//0022-3514.84.1.29

Tafarodi, R. W., Tam, J. i Milne, A. B. (2001.), Selective Memory and the Persistence of Paradoxical Self-Esteem. Personality and Social Psychology Bulletin, 27 (9): 1179-1189. doi:10.1177/0146167201279010

Tice, D. M. (1991.), Esteem Protection or Enhancement? Self-Handicapping Motives and Attributions Differ by Trait Self-Esteem. Journal of Personality and Social Psychology, 60 (5): 711-725. doi:10.1037/ 0022-3514.60.5.711 
DRUŠ. ISTRAŽ. ZAGREB GOD. 21 (2012), BR. $2(116)$

STR. $443-463$

JELIĆ, M.:

NOVE SPOZNAJE...
Trzesniewski, K. H., Donnellan, M. B. i Robins, R. W. (2003.), Stability of Self-Esteem across the Life Span. Journal of Personality and Social Psychology, 84 (1): 205-220. doi:10.1037/0022-3514.84.1.205

Updegraff, J. A., Emanuel, A. S., Suh, E. M. i Gallagher, K. M. (2010.), Sheltering the Self from the Storm: Self-Construal Abstractness and the Stability of Self-Esteem. Personality and Social Psychology Bulletin, 36 (1): 97-108. doi:10.1177/0146167209353331

Verkuyten, M. (1996.), "Twelve angry men". Accounting for Britain's Minority Position during the EU Summit in Maastricht. Journal of Language and Social Psychology, 15 (4): 444-467. doi:10.1177/0261927X 960154003

Whisman, M. A. i Kwon, P. (1993.), Life Stress and Dysphoria: The Role of Self-Esteem and Hopelessness. Journal of Personality and Social Psychology, 65 (5): 1054-1060. doi:10.1037/0022-3514.65.5.1054

Wilson, T. D., Lindsey, S. i Schooler, T. Y. (2000.), A Model of Dual Attitudes. Psychological Review, 107 (1): 101-126. doi:10.1037/0033-295X. 107.1.101

Zeigler-Hill, V. (2006.), Discrepancies between Implicit and Explicit Self-Esteem: Implications for Narcissism and Self-Esteem Instability. Journal of Personality, 74 (1): 119-143. doi:10.1111/j.1467-6494.2005.00371.x

\section{New Findings in Self-Esteem Research: Self-Esteem Security}

Margareta JELIĆ

Faculty of Humanities and Social Sciences, Zagreb

In scientific and popular psychological literature, self-esteem is often mentioned as an indicator of mental health, mature personality and adaptation of an individual. However, recently there has been a growing number of contradictory findings on self-esteem, the reason for which can be found in an old-fashioned approach to investigating self-esteem, i.e. neglecting various aspects of self-esteem, as well as different measures for self-esteem. The aim of this article is to familiarize researchers with new insights in self-esteem research, point out the complexity of the construct and give guidelines for future research. The article explains why the use of different self-esteem measures often results in contradictory findings concerning self-esteem level. We also introduce the construct of self-esteem security that can shed light on the abovementioned contradictory findings. Furthermore, the definition of self-esteem security as well as various operationalisations of this construct are given, and commonalities and differences with related constructs explained. Finally, the article presents results of recent self-esteem research and new findings in this area.

Keywords: self-esteem level, secure self-esteem, implicit self-esteem, paradoxical self-esteem, defensive self-esteem 